\title{
MUITO MAIS QUE DIVERSÃO: CONTRIBUIÇÕES DE MARIA NIKOLAJEVA SOBRE LITERATURA INFANTO-JUVENIL
}

\begin{abstract}
Maria Nikolajeva
Doutora em Literatura Comparada pela Universidade de Estocolmo [Suécia] Professora e Catedrática de Educação na Universidade de Cambridge [Reino Unido]
\end{abstract}

Entrevistada por:

Everaldo Lima de Araújo

Doutorando em Letras - Língua Portuguesa - pela Universidade do Estado do Rio de Janeiro (UERJ) ever.lima.araujo@gmail.com

Márcia da Gama Silva Felipe

Doutoranda em Letras - Língua Portuguesa - pela Universidade do Estado do Rio de Janeiro (UERJ) prof.marciadagama@gmail.com

Thales Sant'Ana Ferreira Mendes

Mestrando em Letras - Literatura Brasileira - pela Universidade do Estado do Rio de Janeiro (UERJ) thales.sanfer@hotmail.com

Maria Nikolajeva nasceu na Rússia e se mudou para a Suécia em 1981. Mestre em Inglês pela Universidade Estadual de Moscou (Rússia) e doutora em Literatura Comparada pela Universidade de Estocolmo (Suécia) - onde trabalhou por 25 anos -, é Professora e Catedrática de Educação na Universidade de Cambridge (Reino Unido). Já foi presidente (1993-1997) da International Research Society for Children's Lierature e uma das editoras seniores da Oxford Encyclopedia of Children's Literature. Em 2005, recebeu o International Brothers Grimm Award pela contribuição de seu trabalho sobre literatura infantil. É autora de mais de 300 artigos e de algumas dezenas de livros, incluindo from mythic to linear: time in children's literature (2000), Power, voice and subjectivity in literature for young readers (2010) e Reading for Learning: cognitive approaches to children's literature (2014). Sua obra mais conhecida no Brasil é Livro ilustrado: palavras e imagens (Cosac Naify, 2011), escrito em 2001, com a professora Carole Scott.

Por e-mail, gentilmente a professora Maria Nikolajeva nos concedeu esta entrevista, carregada de posicionamentos sobre leitura e literatura infanto-juvenil. Com presteza, a professora ainda nos presenteou com a versão em inglês dessa conversa. É possível perceber importantes nuanças reflexivas para além da realidade brasileira, pondo em evidência o escopo dos estudos que tratam da literatura infantil e juvenil, seja no âmbito do ensino e da pesquisa. 


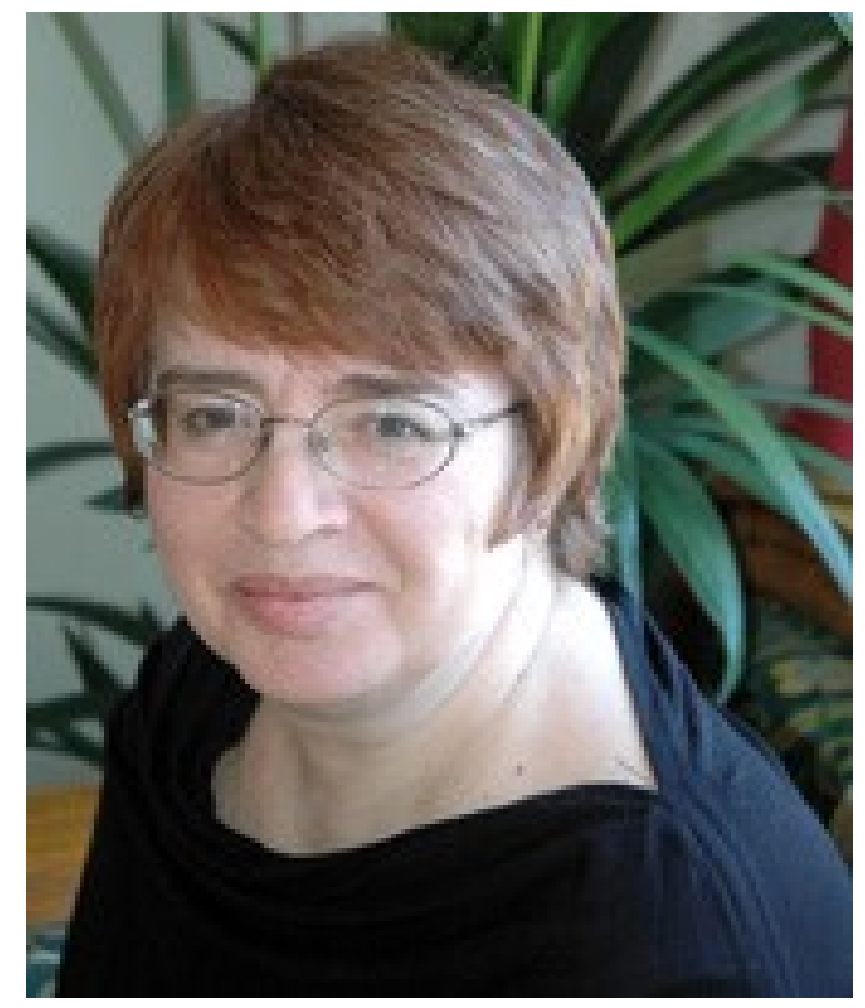

\section{PALIMPSESTO}

1) Houve um tempo em que a literatura infantil era considerada um gênero menor dentro do âmbito literário. A senhora acha que essa visão ainda persiste hoje em dia?

\section{MARIA NIKOLAJEVA}

Até certo ponto, sim, mas isso também é um fato para outros tipos de literatura: ficção popular, quadrinhos, videogames; não são considerados seriamente pelos estudos literários convencionais. No entanto, a literatura infantil atual está alcançando públicos mais velhos, e cada vez mais acadêmicos, de várias disciplinas, para além dos estudos literários, descobrem isso, como nos estudos sobre deficiência, estudos críticos sobre alimentação e, é claro, nos meios de comunicação. Além disso, mais e mais pessoas se tornam conscientes das implicações políticas e sociais da literatura infantil. 


\section{PALIMPSESTO}

2) Qual a relação entre literatura infantil e diversão?

\section{MARIA NIKOLAJEVA}

Não tenho certeza do que você quis dizer com isso. Qualquer forma de arte é, de certa forma, entretenimento, e qualquer forma de arte é educativa, no sentido de que nos diz algo sobre nós mesmos, sobre sermos humanos. A literatura infantil não é uma exceção. Ninguém quer ler livros entediantes, então, naturalmente, eles têm de ser divertidos e cativantes, independentemente de seu público-alvo.

\section{PALIMPSESTO}

3) Muitas escolas adotam alguns livros paradidáticos cuja leitura é obrigatória. Como lidar, nesse caso, com o incentivo à leitura, considerando as avaliações demandadas por essas escolas?

\section{MARIA NIKOLAJEVA}

Se o propósito da leitura é a preparação para as avaliações, é uma oportunidade perdida: as crianças a odiarão. Há várias pesquisas que evidenciam isso. Ler por prazer deveria ser a prioridade; mas sabemos, por experiência própria, que os professores não têm tempo e frequentemente não sabem como favorecer a leitura por prazer. Isso é uma falha sistêmica, que requer esforço conjunto de educadores, formuladores de políticas, autores, editores, bibliotecários e pais. 


\section{PALIMPSESTO}

4) Os livros infantis costumam ter algum comprometimento com o desenvolvimento intelectual de seus leitores?

\section{MARIA NIKOLAJEVA}

Sim. Ler é crucial para o desenvolvimento cognitivo, emocional e social das crianças - todas as pesquisas recentes em neurociência confirmam o que educadores e especialistas em literatura infantil sempre souberam.

\section{PALIMPSESTO}

5) No Brasil, há poucas obras teóricas sobre literatura infantil, embora haja uma grande quantidade de livros infanto-juvenis. Como a senhora entende essa desproporção?

\section{MARIA NIKOLAJEVA}

Pesquisas sobre literatura infantil são uma área relativamente recente, com cerca de 30 a 40 anos no Reino Unido, nos Estados Unidos e em alguns países europeus. Em muitos países, ainda é algo escarço, mesmo naqueles em que há uma publicação massiva para crianças, como na China, Rússia e Índia. Isso leva tempo e demanda entusiastas. Há alguns poucos estudiosos brasileiros de literatura infantil que estão fazendo um trabalho incrível. Mas, até agora, eles não atingiram uma massa crítica para que sejam reconhecidos. 


\section{PALIMPSESTO}

6) How picturebooks work [no Brasil, Livro ilustrado: palavras e imagens] é, provavelmente, o livro mais traduzido da senhora. Considerando o panorama atual dos estudos sobre literatura infantil, como a senhora entende a popularidade e importância desse trabalho?

\section{MARIA NIKOLAJEVA}

Foi um dos primeiros livros inteiramente dedicados aos livros ilustrados enquanto formas de arte (em oposição às aplicações de conteúdo ou pedagógicas). Há muito mais estudos agora, mas alguns deles ganham o status de "obras padrão", às quais qualquer produção acadêmica subsequente sempre se refere. Não é meu livro favorito, e acho que ele está desatualizado porque o próprio livro ilustrado mudou; mas, aparentemente, as pessoas ainda o acham útil, talvez porque não haja outro estudo abrangente sobre livros ilustrados com essa abordagem.

\section{PALIMPSESTO}

7) Que mensagem a senhora deixa para aqueles que procuram despertar em seus alunos o hábito da leitura?

\section{MARIA NIKOLAJEVA}

A primeira coisa, e a mais importante, é a própria pessoa ser um leitor ávido. Seus estudantes nunca abraçarão a leitura se eles não sentirem seu entusiasmo e satisfação. 
Segundo: todos os leitores são diferentes e, como uma promotora de leitura, a pessoa precisa estar apta para oferecer algo para cada leitor - portanto, ela precisa ter uma ampla orientação do que há disponível: clássicos e contemporâneos, diferentes gêneros, fáceis e exigentes, sérios e divertidos. Terceiro: a pessoa precisa ser uma leitora profunda, uma leitora crítica, e ensinar a seus alunos a serem leitores críticos também, que pensem em vez de simplesmente consumir. Mas, para isso, os livros precisam ter qualidades que permitam estimular o pensamento crítico, o que retoma o que eu disse sobre uma ampla orientação. 


\section{MORE THAN AMUSEMENT: CONTRIBUTIONS OF MARIA NIKOLAJEVA ON CHILDREN'S LITERATURE}

Introduction translated by:

Thales Sant'Ana Ferreira Mendes MA student in Brazilian Literature (Universidade do Estado do Rio de Janeiro, UERJ) thales.sanfer@hotmail.com

Maria Nikolajeva was born in Russia and moved to Sweden in 1981. MA in English Language and Literature (Moscow Linguistic University, Russia) and PhD in Comparative Literature (Stockholm University, Sweden), she is Professor and Chair of Education at the University of Cambridge, UK. She was president (1993-1997) of the International Research Society for Children's Literature and one of the senior editors for the Oxford Encyclopedia of Children's Literature. In 2005, she received the distinguished International Brothers Grimm Award for a lifetime achievement in children's literature research; in 2006, she was made Honorary Professor at the University of Worcester, UK. Author of more than three hundred articles and reviews, she also has written a dozen of books, including: From mythic to linear: time in children's literature (2000), Power, voice and subjectivity in literature for young readers (2010) and Reading for Learning: cognitive approaches to children's literature (2014). In Brazil, her most famous work is Livro ilustrado: palavras e imagens (Cosac Naify, 2011), translation of How picturebooks work, written in 2001 with Professor Carole Scott.

The professor Maria Nikolajeva kindly has given us this interview by e-mail, showing her opinions on reading and children's literature. The interview addresses important points that go beyond Brazilian reality, highlighting the scope of studies that deal with children's literature, whether in the field of teaching or research. 


\section{PALIMPSESTO}

1) There was a time children's literature was considered a smaller genre within the literary world. Do you think that this point of view still holds on nowadays?

\section{MARIA NIKOLAJEVA}

To a certain extent, yes, but it is also true about other kinds of literature: popular fiction, comics, videogames; not considered seriously by conventional literary studies. However, children's literature today is crossing over to older audiences, and more and more scholars from various disciplines, apart from literature studies, discover it, such as disability studies, critical food studies and of course media and communication. Also more and more people become aware of the social and political implications of children's literature.

\section{PALIMPSESTO}

2) What is the relation between children's literature and amusement?

\section{MARIA NIKOLAJEVA}

I am not sure what you mean. Any art form is entertaining in some sense, and any art is also educational in the sense that it tells us something about ourselves, about being human. Children's literature is no exception. Nobody wants to read boring books so of course they need to be entertaining and engaging, no matter what audience they target. 


\section{PALIMPSESTO}

3) Many schools adopt some literary textbooks whose reading is mandatory. How to deal, in this case, with reading incentive, considering the exams required by these schools?

\section{MARIA NIKOLAJEVA}

If the purpose of reading is preparation for exams, it's a lost opportunity: children will hate it. There is vast evidence from research on this. Reading for pleasure should be the priority; but we know from real-life experience that teachers have no time and frequently don't know how to support reading for pleasure. This is a systemic fault that needs joint effort from educators, policy-makers, authors, publishers, librarians and parents.

\section{PALIMPSESTO}

4) Do children's books use to have any commitment to the intellectual development of their readers?

\section{MARIA NIKOLAJEVA}

Yes. Reading is crucial for children's cognitive, emotional and social development all recent research in neuroscience confirms what educators and children's literature scholars have always known. 


\section{PALIMPSESTO}

5) In Brazil, there are few theoretical works on children's literature, although there is a great deal of children's books. How do you understand this imbalance?

\section{MARIA NIKOLAJEVA}

Children's literature research is a relatively new area, about 30-40 years in the UK, USA and some European countries. In many countries it is still scarce, even in countries that have massive publishing for children, such as China, Russia or India. It takes time, and it needs enthusiasts. There are quite a few Brazilian scholars of children's literature who are doing amazing work. But they have so far not reached a critical mass to be acknowledged.

\section{PALIMPSESTO}

6) How picturebooks work is probably your most translated book. Considering the current outlook on children's literature studies, how do you understand the popularity and importance of this work?

\section{MARIA NIKOLAJEVA}

It was one of the first books wholly dedicated to picturebooks as a art form (as opposed to content or pedagogical applications). There are many more studies now, but some studies gain the status of "standard works" that every subsequent scholarship refers to. It is not my favourite book, and I think it is outdated because the picturebook 
Maria Nikolajeva, Everaldo L. de Araújo, Márcia da Gama S. Felipe e Thales Sant'Ana F. Mendes

itself has changed, but apparently people still find it useful, maybe because there is no other comprehensive study of picturebooks with such an approach.

\section{PALIMPSESTO}

7) What message do you leave to those ones who try to arouse in their students the habit of reading?

\section{MARIA NIKOLAJEVA}

The first and most important thing is to be an avid reader yourself. Your students will never embrace reading if they do not feel your enthusiasm and enjoyment. Second, all readers are different, and as a reading promoter you need to be able to offer something to every reader - therefore you need to have a broad orientation in what is available: classics and contemporary, various genres, easy and demanding, serious and entertaining. Third, you need to be a deep reader, a critical reader and teach your students to be critical readers, thinking rather than simply consuming. But for this purpose, books need to have qualities that allow and stimulate critical thinking, which goes back to having a broad orientation. 